\title{
HUBUNGAN STATUS GIZI DENGAN AGILITY PADA PEMAIN FUTSAL USIA 12- 16 TAHUN DI KLUB FUTSAL SAHABAT JUNIOR PANGKALAN LESUNG
}

\author{
${ }^{1)}$ Ruswaldi Munir, ${ }^{2)}$ Nova Sukma \\ ${ }^{1)}$ Departemen Ilmu Faal Kedokteran, Program Studi Pendidikan Dokter, Fakultas Kedokteran, Universitas \\ Abdurrab \\ ${ }^{2)}$ Program Studi Pendidikan Dokter, Fakultas Kedokteran, Universitas Abdurrab \\ ${ }^{1,2} \mathrm{Jl}$. Riau Ujung No. 73 Pekanbaru - Riau - Indonesia, 28292 \\ E-mail : ${ }^{1)}$ ruswaldi.munir@univrab.ac.id, ${ }^{2)}$ nova.sukma.17@student.univrab.ac.id
}

Kata Kunci: agility,futsal, status gizi

Keywords: agility, futsal, nutrition status

\section{Info Artikel}

Tanggal dikirim: 15-1-2021

Tanggal direvisi: 22-1-2021

Tanggal diterima: 291221

DOI Artikel:

10.36341/cmj.v4i1

.2160

Attribution-

NonCommercial 4.0

International. Some

rights reserved

\begin{abstract}
ABSTRAK
Agility merupakan faktor penting dalam kesuksesan permainan futsal. Ada beberapa faktor pendukung agar pemain dapat melakukan teknik dan strategi permainan futsal, seperti tinggi badan dan berat badan. Olahraga futsal merupakan olahraga yang membutuhkan banyak teknik dan strategi dalam menciptakan permainan yang baik. Futsal adalah olahraga yang sangat digemari oleh kalangan remaja, terutama remaja yang tergolong dalam remaja awal yaitu usia 12-16 tahun. Pada golongan ini, terjadinya perkembangan fisik yang pesat dan aktif dalam berbagai jenis cabang permainan namun kalangan remaja saat ini memiliki kebiasaan yang kurang sehat seperti tidak sarapan, kurang mengkonsumsi sayur dan buah yang merupakan sumber dari serat dan sering mengkonsumsi makanan berpenyedap. Kebiasaan yang kurang sehat tersebut dapat menyebabkan berat badan yang tidak ideal dan gangguan dalam keseimbangan status gizi yang merupakan salah satu masalah nutrisi dalam mengoptimalkan permainan futsal. penelitian ini bertujuan untuk mengetahui hubungan status gizi dengan agility pada pemain futsal berusia 12-16 tahun di klub futsal Sahabat Junior Pangkalan Lesung. Metode penelitian menggunakan analitik observasional dengan pendekatan cross sectional. Penelitian dilakukan terhadap klub futsal Sahabat Junior Pangkalan Lesung. Teknik Pengambilan sampel dengan cara total sampling. Setelah disesuaikan dengan kriteria inklusi dan eksklusi sampel menjadi 35 responden. Hasil penelitian p-value 0,580, hal tersebut menunjukkan tidak dapat hubungan korelasi yang bermakna antara status gizi dengan agility pada pemain futsal usia 12-16 tahun di klub futsal Sahabat Junior Pangkalan Lesung.
\end{abstract}

\section{ABSTRACT}

Agility is an important factor in the success of futsal. There are several supporting factors so that players can carry out futsal game techniques and strategies, such as height and weight. Futsal is a sport that is very popular with teenagers, especially teenagers who are classified as early teens, namely the age of 12-16 years, in this group there is rapid physical development and is active in various types of branches of the game, but today's teenagers have bad habits. healthy habits such as not having breakfast, consuming less vegetables and fruit which are sources of fiber and often consuming flavored foods, these unhealthy habits can lead to non-ideal body weight and disturbances in the balance of nutritional status which is one of the nutritional problems in optimizing the game of futsal. The research to determine the relationship between nutritional status and agility in futsal players aged 1216 years at the futsal club Sahabat Junior Pangkalan Lesung. This research method uses analytic observational with cross sectional approach. This research was conducted at the futsal club Sahabat Junior Pangkalan Lesung. The sampling technique was totalsampling. After adjusting to the inclusion and exclusion criteria the sample became 35 respondents. The results of the research p-value 0.580 showed that there was no significant relationship between nutritional status and agility in futsal players aged 12-16 years at the Sahabat Junior futsal club in Pangkalan Lesung. 


\section{PENDAHULUAN}

Futsal adalah olahraga tim yang populer dan dimainkan oleh pria dan wanita diseluruh dunia, baik dari pemain pemula hingga pemain profesional. Futsal dimulai pertama kali di Negara-negara Amerika Selatan pada tahun 1930, yaitu di Uruguay dan Brasil. Kota-kota yang penuh sesak dan kekurangan lapangan di Brasil membuat penduduk pencinta bola untuk bermain di lapangan yang kecil. Futsal adalah nama yang ditetapkan oleh Federation International de Football Association (FIFA) untuk satu-satunya versi sepakbola Five-A-Side [1].

Olahraga futsal merupakan olahraga yang membutuhkan banyak teknik dan strategi. Futsal merupakan olahraga yang membutuhkan pola pergerakan yang cepat, berlari dengan cepat dan ketepatan dalam mengambil keputusan untuk mempertahankan penguasaan bola. Dalam permainan futsal yang menjadi hal terpenting dalam mencapai kesuksesan permainan adalah kelincahan. Kelincahan atau agility didefinisikan sebagai kemampuan untuk mengubah arah secara cepat dan akurat dalam mengambil suatu keputusan. Menerapkan istilah kelincahan menggambarkan setiap gerakan olahraga yang dinamis yang melibatkan perubahan posisi tubuh. Ada beberapa faktor pendukung agar pemain dapat melakukan teknik dan strategi permainan, seperti tinggi badan dan berat badan [2].

Ditinjau dari penelitian Sangadah (2020) dan Syahfitri Ernalia \& Restuastut (2017) dilakukan survey pemilihan minat ekstrakulikuler di SMP dan SMA, didapatkan hasil bahwa pemilih terbanyak diperoleh oleh ekstrakulikuler futsal [3][4]. Kelompok usia remaja merupakan kelompok usia yang memiliki minat yang tinggi terhadap permainan futsal, baik dari Sekolah Menengah Pertama (SMP) dan Sekolah Menengah Atas (SMA). Remaja dapat diklasifikasikan menjadi remaja awal yang berusia 12-16 tahun dan remaja akhir dengan usai 17-25 tahun. Masa remaja memiliki masa pertumbuhan yang cepat, dan terjadi perubahan dramatis pada komposisi tubuh yang mempengaruhi aktifitas fisik dan merespon terhadap latihan. Perkembangan pesat ini terutama berlangsung pada usia 12-16 tahun pada remaja laki-laki. ciri psikomotor yang dialami oleh remaja awal yaitu, ciri gerakgerik tampak canggung dan kurang terkoordinasikan dan aktif dalam berbagai jenis cabang permainan. Oleh karena itu, asupan gizi anak- anak yang aktif harus sesuai dengan meningkatnya kebutuhan daya (energy), vitamin, mineral dan nutrisi lainya. Remaja saat ini memiliki pola makan yang tidak teratur, sebagian besar dari asupan nutrisinya diperoleh dari makanan-makanan snacks, dan bahkan sering melupakan sarapan dan makan siang kebiasaan tersebut dapat menyebabkan berat badan yang tidak ideal dan gangguan dalam keseimbangan gizi yang merupakan salah satu masalah nutrisi dalam mengoptimalkan massa tubuh pamain futsal [5].

Golongan usia remaja adalah golongan yag aktif sehingga tidak sedikit dari mereka memilih untuk aktif dalam bidang futsal dengan mengikuti klub binaan yang diselenggarakan oleh pihak di luar sekolah mereka. Klub futsal Sahabat Junior Pangkalan Lesung merupakan klub binaan dalam bidang futsal yang didirikan pada tahun 2019, seluruh dari peserta klub selalu dilatih dan dibina untuk mempersiapkan diri dalam mengikuti perlombaan. Klub ini merupakan klub yang dibentuk dengan dasar tujuan untuk meningkatkan kemampuan dan skill anak remaja yang memiliki minat yang tinggi terhadap permainan futsal.

Berdasarkan penjelasan latar belakang di atas, maka akan dilakukan penelitian terhadap tim futsal Sahabat Junior Pangkalan Lesung. Mengetahui hal tersebut maka peneliti berminat untuk malakukan penelitian dengan judul "Hubungan Status Gizi Dengan Agility Pada Pemain Futsal Usia 12-16 Tahun Di Klub Futsal Sahabat Junior Pangkalan Lesung ". 


\section{METODE}

Jenis penelitian yang digunakan dalam penelitian ini adalah analitik observasional dengan pendekatan cross sectional, yaitu pengambilan data variabel independen dan variabel dependen dilakukan dalam satu waktu atau satu kali ukur dalam waktu yang bersamaan yang dilakukan untuk menganalisis hubungan antara variabel independen status gizi dengan variabel dependen agility pada

pemain futsal usia 12-16 tahun di klub futsal Sahabat Junior Pangkalan Lesung. Penelitian ini dilakukan di lapangan futsal Kecamatan Pangkalan Lesung Kabupaten Pelalawan provinsi Riau. Teknik pengambilan sampel yang digunakan adalah total sampling yang merupakan seluruh pemain klub futsal Sahanat Junior Pangkalan Lesung. Penelitian ini dilakukan kepada seluruh pemain klub futsal Sahabat Junior Pangkalan Lesung yang berusia 12-16 tahun, dan yang menjadi sampel sebanyak 35 responden yang telah memenuhi syarat dari kriteria inklusi dan eksklusi.

Instrumen yang digunakan pada penelitian ini yaitu alat yang digunakan untuk mengukur status gizi. Alat yang digunakan untuk menentukan status gizi (IMT/U) :

a. Timbangan badan untuk mengukur berat badan, Pengukuran ini menggunakan timbangan badan elektrik.

b. Stature meter yang digunakan mengukur tinggi badan dari responden

Kemudian tes yang digunakan untuk mengukur tingkat agility/ kelincahan responden yaitu, dengan menggunakan allinois agility run test.

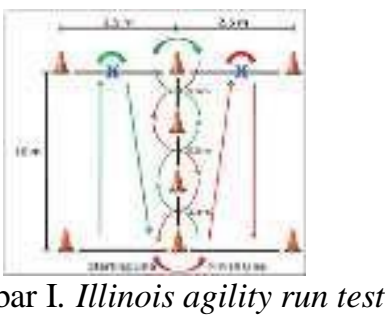

HASIL DAN PEMBAHASAN

Analisis univariat dilakukan untuk melihat gambaran karakteristik responden. Berikut hasil analisis univariat terhadap karakteristik responden.

Tabel 1. Karakteristik Usia Pemain klub futsal Sahabat Junior PangkalanLesung

\begin{tabular}{|c|c|c|}
\hline $\begin{array}{c}\text { Usia } \\
\text { responden }\end{array}$ & Frekuensi & Presentasi \\
\hline 12 & 14 & $40 \%$ \\
\hline 13 & 4 & $11,4 \%$ \\
\hline 14 & 7 & $20 \%$ \\
\hline 15 & 6 & $17,1 \%$ \\
\hline 16 & 4 & $11,4 \%$ \\
\hline
\end{tabular}

Tabel 2. Karakteristik Berdasarkan Status Gizi Pemain Klub Futsal Sahabat Junior Pangkalan Lesung

\begin{tabular}{ccc}
\hline $\begin{array}{l}\text { Kriteria status } \\
\text { gizi }\end{array}$ & Frekuensi & $\begin{array}{c}\text { Presentasi } \\
(\boldsymbol{\%})\end{array}$ \\
\hline Sangat kurus & 2 & $5,7 \%$ \\
\hline Kurus & 5 & $14,3 \%$ \\
\hline Normal & 24 & $68,6 \%$ \\
\hline Gemuk & 1 & $2,9 \%$ \\
\hline Obesitas & 3 & $8,6 \%$ \\
\hline Total & 35 & $100 \%$ \\
\hline
\end{tabular}

\begin{tabular}{ccc}
\hline $\begin{array}{c}\text { Kriteria } \\
\text { agility }\end{array}$ & Frekuensi & $\begin{array}{c}\text { Presentasi } \\
(\%)\end{array}$ \\
\hline Baik & 3 & $8.6 \%$ \\
\hline Sedang & 15 & $42.9 \%$ \\
\hline $\begin{array}{c}\text { Kurang } \\
\text { kutang }\end{array}$ & 5 & $14.3 \%$ \\
\hline \begin{tabular}{c} 
Totaltgat \\
\hline
\end{tabular} & 35 & $3403 \%$ \\
\hline
\end{tabular}

Tabel 3. Karakteristik berdasrkan agility pemain klub futsal Sahabat Junior Pangkalan Lesung 
Selain analisis univariat digunakan analisis bivariat untuk melihat hubungan status gizi dengan agility pada pemain futsal usia 1216 tahun di klub futsal Sahabat Junior Pangkalan Lesung.

\section{Tabel 4. Hasil Uji Korelasi Spearman Pada Pemain Futsal Usai 12-16 Tahun di Klub Futsal Sahabat Junior Pangkalan Lesung}

\begin{tabular}{|c|c|c|c|c|}
\hline \multirow{3}{*}{$\begin{array}{l}\text { Spear } \\
\text { man's }\end{array}$} & \multirow{3}{*}{ Agility } & & \multicolumn{2}{|c|}{ Agility Status Gizi } \\
\hline & & (r) & 1.000 & .097 \\
\hline & & p-velue & . & .580 \\
\hline \multirow{4}{*}{ rho } & & $\mathrm{N}$ & 35 & 35 \\
\hline & \multirow{3}{*}{$\begin{array}{l}\text { Status } \\
\text { Gizi }\end{array}$} & (r) & .097 & 1.000 \\
\hline & & p-velue & .580 & \\
\hline & & $\mathrm{N}$ & 35 & 35 \\
\hline
\end{tabular}

Berdasarkan Tabel 4 hasil analisis korelasi spearman di atas, diperoleh status gizi dengan agility pada pemain futsal usia 12-16 tahun di klub futsal Sahabat Junior Pangkalan Lesung dengan p-value yaitu $0,580(>0,05)$. Hal tersebut menunjukkan terdapat hubungan korelasi yang tidak bermakna. Didapatkan Nilai koefisien korelasi sebesar 0,97 Hal tersebut menunjukkan terdapat kekuatan hubungan korelasi yang sangat lemah, antara status gizi dengan agility pada pemain futsal usia 12-16 tahun di klub futsal Sahabat Junior Pangkalan Lesung. Penelitian ini sesuai dengan penelitian (Mubarani, Azhar and Septadina, 2017) dengan hasil tidak terdapat hubungan yang signifikan antara indeks massa tubuh (IMT) dengan kelincahan [6]. Kelincahan juga dipengaruhi oleh faktor-faktor lain seperti postur tubuh, berat badan, tinggi badan, satatus gizi, konsumsi lemak, konsumsi kalsium, serta aktivitas fisik (intensitas latihan) [7] dan inilah mengapa konsumsi kalsium dan latihan perlu memadai untuk memberikan elastisitas pada otot tungkai agar otot tersebut sanggup untuk berontraksi dan berelaksasi dengan baik sehingga dapat menghasilkan kelincahan [8]. Hal tersebut yang dapat menjadi salah satu faktor yang menyebabkan hasil penelitian ini tidak terdapat hubungan yang bermakna antara status gizi dan agility pada pemain futsal Sahabat Junior. Penelitian ini juga sejalan dengan penelitian (Gunnar Mathisen and Pettersen, 2015) dengan hasil tidak terdapat hubungan yang signifikan antara IMT dengan agility, hal tersebut terkait dengan proses pematangan dan percepatan pertumbuhan pada anak tersebut, proses maturasi pada sistem musculoskeletal mempengaruhi tingkat kelincahan anak [9].

Berdasarkan tabel 2, Pada penelitian ini didapatkan status gizi yang

bervariasi, namun lebih banyak yang memiliki kriteria status gizi normal yaitu sebanyak 24 orang dengan presentasi $68,6 \%$. Sedangkan yang memiliki status gizi gemuk 1 orang $(2,9 \%)$, dan yang memiliki status gizi obesitas sebanyak 3 orang $(8,6 \%)$. Kemudian yang memiliki status gizi kurus 5 orang $(14,3 \%)$, dengan status gizi sangat kurus sebanyak 2 orang $(5,7 \%)$. Tingkat status gizi pada responden diukur dengan melakukan timbangan berat badan dan tinggi badan, yang kemudian digunakan untuk menghitung Indeks Massa Tubuh (IMT) dari setiap responden. Indeks Massa Tubuh yang didapatkan akan disesuaikan dengan usia yang telah tersedia di dalam tabel standar Indeks Massa Tubuh Menurut Umur (IMT/U) anak laki-laki umur 12-16 tahun. Sehungga didapatkan hasil bahwa status gizi mereka bervariasi, sebagian besar dari mereka memiliki status gizi normal namun sebagian lainnya memiliki status gizi yang sangat kurus, kurus, gemuk dan obesitas.

Pada penelitian ini didapatkan status gizi dari responden mayoritas normal. Hal tersebut dapat disebebkan oleh jumlah kalori yang dikonsumsi oleh pemain seimbang dengan jumlah kalori yang digunakan untuk beraktivitas. Pemain memiliki waktu latihan sebanyak 2 kali dalam seminggu, sehingga aktivitas tersebut dapat menyebabkan penggunaan kalori yang diubah dalam bentuk energi, dan tidak terjadinya penumpukan lemak dalam tubuh pemain dari kalori yang dikonsumsi. Ataupun tidak terjadinya pemecahan protein yang digunakan untuk 
energi pada saat kalori berkurang pada tubuh pemain. Hal tersebut yang menyebabkan status gizi dari mereka dalam batas normal. Olahraga yang dilakukan oleh para pemain bukan hanya sekedar aktivitas fisik yang bertujuan untuk membakar kalori dalam tubuh, tetapi lebih dari itu bahkan sangat menguras energi dalam tubuh. Intensitas, kerutinan serta teraturnya olahraga yang dilakukan mempengaruhi terhadap status gizi pemain [10].

Pada penelitian ini terdapat status gizi yang gemuk $1(2,9 \%)$ responden dan obesitas $3(8,6 \%)$ responden. Menurut penelitian (Syahfitri, Ernalia \& Restuastut, 2017) mengemukakan bahwa sebagian remaja yang memiliki masalah terhadap status gizi yang mereka alami, salah satunya adalah disebabkan faktor remaja yang sering mengkonsumsi makanan siap saji, dan didukung dengan ketersediaan harga makanan yang murah, cepat tetapi tidak sehat seperti junk food. Akibat dari konsumsi makanan cepat saji tersebut dapat meningkatkan 6 kali lipat seorang remaja tersebut menjadi gemuk dan obesitas [4]. Remaja cenderung memiliki sifat konsumtif, serta memiliki pola konsumsi tidak beraturan karena pada masa remaja merupakan tahap pertumbuhan sehingga cenderung untuk memilih makanan yang mengugah selera serta biasanya memiliki kadar glukosa dan lemak yang cukup tinggi. Jenis makanan inilah yang berdampak pada berat badan yang berlebih [11]. Sehingga dimungkinkan dari 4 responden ini lebih suka mengkonsumsi makanan dengan kadar glukosa dan lemak yang tinggi dan tingkat aktifitas yang kurang yang menyebabkan responden memiliki status gizi gemuk dan obesitas.

Pada penelitian ini terdapat status gizi yang sangat kurus sebanyak $2(5,7 \%)$ responden dan yang status gizi kurus sebanyak $5(14,3 \%)$ responden. Tubuh seseorang yang kurus umumnya disebabkan oleh ketidakseimbangan antara energi yang masuk dan energi yang keluar dari tubuh, energi yang keluar jauh lebih besar dari yang masuk. Hal ini bisa disebabkan oleh kurang makan, menu makanan yang tidak seimbang, nafsu makan menurun atau aktivitas fisik yang tidak seimbang. Penyebab lain yang sering ialah, penyakit kronis seperti TBC, diabetes, kanker, penyakit saluran pencernaan atau penyakit lain yang menyebabkan turunnya nafsu makan. Pada penyakit infeksi umunya terjadi peningkatan metabolisme tubuh dan pemecahan jaringan yang memerlukan energi ekstra, selain itu orang yang kurus ada kemungkinan karena konstitusi atau pembawaannya. Bobot badan orang seperti ini biasanya kurang karena rangka dan otot-otot kecil. Untuk menghindari terjadinya gizi kurang, makanan yang dikonsumsi remaja harus bervariasi antara kandungan karbohidrat, protein,lemak, vitamin dan mineralnya [4].

Berdasarkan tabel 3 didapatkan agility atau tingkat kelincahan pemain futsal usia 12-16 tahun di klub futsal Sahabat Junior Pangkalan Lesung memiliki kriteria yang bervariasi namun didominasi oleh tingkat agility yang sedang yaitu sebanyak 15 orang dengan presentasi 42,9\%. Sedangkan yang memiliki agility yang baik sebanyak 3 orang $(8,6 \%)$, dengan tingkat agility yang kurang sebanyak 5 orang $(14,3 \%)$, dan yang memiliki tingkat agility yang kurang sekali sebanyak 13 orang $(37,1 \%)$ yang memiliki nilai selisih yang sedikit dengan responden yang memiliki tingkat agility sedang. 
Beberapa hal yang menuyebabkan bervariasinya hasil tingkat agility pada responden, yaitu kurangnya perhatian pelatih terhadap latihan yang dilakukan oleh responden yang dapat meningkatkan agility setiap responden. Latihan yang sering dilakukan oleh responden setiap minggu terhadap pemain hanyalah latihan battle, latihan ini tidak termasuk sebagai latihan yang dapat meningkatkan agility, sehingga responden belum memiliki tingkat agility yang sangat baik dan hanya mendominasi pada tingkat agility sedang.

Pada penelitian ini didominasi oleh usia 12 tahun yang merupakan pemain yang baru bergabung di dalam klub ini sehingga responden usia 12 tahun tersebut dimungkinkan intensitas latihannya masih sedikit dibandingkan pemain yang lama, hal tersebut yang menyebabkan jumlah respoden yang memiliki agility yang kurang sekali begitu banyak dan hanya memiliki selisih yang sedikit dengan jumlah responden yang memiliki agility yang sedang.

Dalam analisis komponen dasar fisiologi yang merupakan faktor-faktor dalam kelincahan yaitu : Luas pergerakan persendian untuk meningkatkan kelentukan/ fleksibilitas, kekuatan otot dan koordinasi fungsi otot. Kemampuan komponen tersebut dipengaruhi oleh frekuensi tingkat latihan, adapun latihan yang dapat dilakukan adalah lari zig-zag, shuttle run, squat thrust. Latihan tersebut yang kurang difokuskan oleh pelatih pada saat latihan yang dilakukan oleh reaponden. Usia merupakan faktor penting dalam agility semakin mendekati usia dewasa maka kekuatan otot juga akan bertambah sehingga agililty yang dihasilkan juga akan lebih baik [12].

Penelitian tidak sesuai dengan penelitian (Islamiyati et al., 2021) kebugaran jasmani dan status gizi yang baik akan menghasilkan kelincahan gerak yang baik. Satatus gizi yang tidak seimbang pada remaja dapat menyebabkan terjadinya gangguan perkembangan dan pertumbuhan karena manusia membutuhkan energi ketika melakukan gerakan, energi yang digunakan berasal dari makanan yang cukup mengandung nilai gizi yang baik [13]. Hal tersebut membuat remaja akan terlihat semangat,gesit dan aktif dalam melakukan gerakan atau aktivitas sehingga dapat meningkatkan daya tahan otot, kelentukan, koordinasi yang menghasilkan gerakan yang baik. Penelitian ini tidak sejalan dengan penelitian (Saputra et al.,2019) yang menyatakan semakin besar bentuk tubuh seorang atlit maka akan terbentuknya semakin kurang lincah serta kurang tangkas dalam mengganti posisi badan secara efektif sehingga hasil penelitinnya mendapatkan terdapatnya korelasi lemak terhadap nilai skor kelincahan, namu selain dari status gizi, kelincahan juga dipengaruhi oleh intensitas latihan [14]. (Dhapola and Verma, 2017) menyatakan apabila seseorang memiliki bobot berat badan normal namun tidak melangsungkan latihan fisik secara tertata dan tertruktur maka performa kelincahannya belum tentu baik, dan kelincahan dipengaruhi oleh beberapa faktor seperti usia, jenis kelamin, status gizi, penggunaan tenaga, konsumsi protein, konsumsi karbohidrat, postur tubuh, status kesehatan, intensitas latihan, serta keletihan. Komponen ini saling berkaitan satu sama lain untukmeningkatkan kelincahan [2].

Pada hasil penelitian ini tidak terdapat hubungan yang bermakna antara status gizi dengan agility pada pemain futsal usia 12-16 tahun di klub futsal Sahabat Junior Pangkalan Lesung hal ini dapat dipengaruhi oleh faktor motivasi intrinsik dan ektrinsik responden, faktor motivasi intrinsik meliputi prestasi, pengakuan, tantangan, dan kemajuan. Faktor intrinsik merupakan faktor yang lebih baik dalam memberikan motivasi pemain. Sedangkan motivasi ekstrinsik yaitu Dorongan ini berasal dari pelatih, guru, orangtua, pembina, hadiah, sertifikat, penghargaan atau uang [15]. Faktor intrinsik dan faktor ektrinsik itulah yang seharusnya didapat oleh responden pada saat pengambilan data untuk mengasilkan performa pada saat tes agility maksimal, namun hal tersebut tidak dapat dikendalikan oleh peneliti. 
Menurut penelitian (Hariadi,Riyad Fadhli \& Sandy Yudasmara, 2019) didapatkan kesimpulan hasil penelitian yaitu tidak terdapat hubungan yang bermakna antara indek massa tubuh dengan agility baik pada anak perempuan maupun anak lakilaki. Agility/Kelincahan meningkat karena faktor yang mempengaruhi kelincahan antara lainkekuatan otot rangka. Kekuatan otot rangka mengalami peningkatan sejalan dengan bertambahnya usia anak, dalam kelompok usia yang sama tetapi meningkat seiring bertambahnya usia untuk anak lakilaki dan perempuan [12].

Terdapat beberapa hal yang menyebabkan hasil pada penelitian ini tidak terbukti, yaitu latihan yang kurang berfokus terhadap peningkatan agility para pemain klub futsal Sahabat Junior Pangkalan Lesung yang memiliki pengaruh besar terhadap peningkatan agility pemain, yaitu dalam meningkatkan kekuatan otot dan fungsi koordinasi. Kemudian usia yang mendominasi pada klub ini, yaitu pada usia 12 tahun yang mana pada usia ini belum terjadinya maturasi pada otot rangka, kelincahan/agility meningkat karena faktor yang mempengaruhi kelincahan antara lain kekuatan otot rangka, dan Pengaruh faktor intrinsik dan ekstrinsik yang tidak didapatkan oleh pemain pada saat pengukuran agility, sehingga pada pengukuran agility responden tidak dilakukan dengan maksimal. Sehingga hal tersebut yang menyebabkan tingkat agility para pamain belum baik meskipun responden memiliki satatus gizi yang normal.

\section{KESIMPULAN}

Dari hasil penelitian hubungan status gizi dengan agility pada pemain futsal di klub futsal sahabat junior pangkalan lesung didapatkan $p$-value $=$ 0,580 yaitu lebih besar dari 0,05 yang menunjukkan bahwa tidak terdapat hubungan yang bermakna antara status gizi dengan agility pada pemain futsal usia 1216 tahun di klub futsal Sahabat Junior Pangkalan Lesung.

\section{DAFTAR PUSTAKA}

[1] Yustika, G. P., Iswati, S. and Subagyo, A. (2019) „Health and Sport Futsal " $\mathrm{s}$ Inside Human Sport Physiology: A Literatures Description"e, Journal of PhysicalEducation, 6(30), pp. 34-42.

[2] Dhapola, M. and Verma, B. (2017) „4(2): 313-315 Relationship of body mass index with agility and speed of university players ${ }^{\mathrm{ee}}, \sim 313 \sim$ International Journal of Physical Education, Sports and Health, 4(2), pp. 313-315.

[3] Sangadah, Khotimatus (2020) „ANALISIS MINAT PADA KEGIATAN

EKSTRAKURIKULER FUTSAL SMA NEGERI 8 MAROS"e, Orphanet Journal of Rare Diseases, 21(1), pp. 1-9.

[4] Syahfitri, Y., Ernalia, Y. and Restuastut, T. (2017) „Gambaran Status Gizi Siswa-Siswi Smp Negeri 13 Pekanbaru Tahun 2016"e, Jurnal online mahasiswa fakultas kedokteran, 4(9), pp. 1689-1699. Available at: https://www.neliti.com/publications/ 184062/gambaran-status-gizi-siswasiswi-smp-negeri-13-pekanbarutahun-2016.

[5] Kemenkes (2017) „Penilaian Status Giziee, p. 315.

[6] Mubarani, E. R., Azhar, M. B. and Septadina, I. S. (2017) „Hubungan Kelincahan dengan Indeks Massa Tubuh dan Persentase Lemak Tubuh pada Siswa SMA Olahraga Negeri Sriwijaya Palembang meningkatkan kebugaran jasmani dan gerakan pembudayaan pola hidup sehat yang bermanfaat bagi kesehatan jasmani , psikologis, dan $\mathrm{M}^{\mathrm{ee}}$, Biomedical Journal of Indonesia: Jurnal Biomedik Fakultas Kedokteran Universitas Sriwijaya, 3(1), pp. 110.

[7] Rudiyanto, D. (2012). Hubungan Berat Badan Tinggi Badan Dan Panjang Tungkai Dengan 
Kelincahan. Journal of Sport Sciences and Fitness, 1(2), 26-31.

[8] Desiplia, R., Indra, E. N., \& Puspaningtyas, D. E. (2018). Asupanenergi, konsumsi suplemen, dan tingkat kebugaran pada atlet sepakbola semi- profesional. Ilmu Gizi Indonesia, 2(1), 39.Syukaisih. 2015.

[9] Gunnar Mathisen and Pettersen, S. A. (2015) ,Anthropometric factors related to sprint and agility performance in young male soccer players"e, Open Access Journal of Sports Medicine, p. 337. doi: 10.2147/oajsm.s91689.

[10] Arini, L. A. and Wijana, I. K. (2020) „Korelasi Antara Body Mass Index (BMI) Dengan Blood Pressure (BP) Berdasarkan Ukuran Antropometri Pada Atlet"e, JURNAL KESEHATAN PERINTIS (Perintis's Health Journal), 7(1), pp. 32-40. doi: 10.33653/jkp.v7i1.390.

[11] Rizqi, H. and Udin, I. (2018) „Hubungan Asupan Karbohidrat Dan Status Gizi Dengan Tingkat Kebugaran Jasmani Pada Atlet Basket Remaja Siswa Sekolah Menengah Pertama ${ }^{e e}$, Media Gizi Indonesia, 11(2), p. 182. doi: 10.20473/mgi.v11i2.182-188.

[12] Hariadi, I., Riyad Fadhli, N. and Sandy Yudasmara, D. (2019)

„Relationship Between Body Mass Index (BMI) With Agility of Elementary School Children ${ }^{\text {ee }}$, (March). doi: 10.2991/icssh18.2019.23.

[13] Islamiyati, N. et al. (2021) „The Relationship Of Nutritional Status, Energy And Nutrients Intake To The Speed And Agility Hockey Extracurricular Partisipants Senior High School At Tangerang Regencye, 13(1), pp. 124-142.

[14] Saputra, R. P. S., Tursilowati, S., Larasati, M. D., \& Sunarto, S. (2019). Hubungan Asupan Lemak, Persen Lemak Tubuh, Somatotype Dengan Kelincahan Atlet Sepakbola Diklat Salatiga Training Centre
(Stc). Jurnal Riset GizI, 7(1), 21.

[15] Muskanan, K. (2015) „Analisis Motivasi Berprestasi Atlet Pusat Pendidikan dan Latihan Olahraga Pelajar Provinsi Nusa Tenggara Timure $^{\text {"e }}$ JKAP (Jurnal Kebijakandan Administrasi Publik), 19(2), p. 105. doi: 